\title{
Determining Specialties of the Jordanian Court of Cassation in Its Civil Capacity (According to Reality and the Law)
}

\author{
Jalal Aead Shwarah ${ }^{1}$ \\ ${ }^{1}$ Civil Law Lecturer, World Islamic Sciences and Education University (WISE), Jordan \\ Correspondence: Jalal Aead Shwarah. E-mail: Jalal_lawyer@yahoo.com
}

Received: July 10, 2019

Accepted: July 20, 2019

Online Published: August 30, 2019

doi:10.5539/ass.v15n9p14

URL: https://doi.org/10.5539/ass.v15n9p14

\begin{abstract}
The main objective of this research is to address the issue determining specialties of the Jordanian court of cassation according to reality and the law.

To achieve this objective, the analytical comparative research design method is used depending on the legal legislations and the diligence of the Judiciary to remove ambiguity form them because of their importance and direct effect in determining specialty of court of cassation and to distinguish it from court of subject.

This research is divided into two subjects: The essence of reality and essence of the law.

The second topic has addressed specialty of court of cassation according to reality and the law, divided into two requirements: considering court of cassation as the upper Judicial body, and the second requirement about considering court of subject third degree of the Jurisdiction degrees.

The research reached the presence of contradictions making it difficult to determine and to set a specific standard and the decisive line between what is reality and what is law.

Based on the results, it is recommended the necessity for in-depth review and amendment of these two laws, setting independent legal texts for the civil trials principal law, organizing the Judges' authority technically to separate between reality and the law.
\end{abstract}

Keywords: court of cassation, court of subject, reality, specialties, law

\section{Introduction}

This research aimed at examining reality and the law to distinguish between them because of the theoretical and practical importance of this subject, the concept of reality and the law and demystifying them will have the direct impact in determining the Jurisdiction of court of cassation.

It is inconceivable to distinguish between what is reality and what is a law and to set a separating line because they are not seen as two sides of one coin. The practical reality aborts each attempt to distinguish them. This is because the opponents are unable to present the facts of the conflict in isolation from the law, the best proper legal adaptation of the facts represented in their case, thereby adding to the facts legal description consistent with what they claim to be in their knowledge, knowing that they are un-obligatory to the Judge. The Judge is obliged to search for the legal basis that fits and applies perfectly to the reality provided by the litigants, so that the claim is consistent with the proper legal logic.

Therefore, the abstract reality which does not carry legal adjustment and which is difficult to obtain in isolation from the proper legal logic, abstract objectivity, which can be trusted without making improvement to be standalone.

Review of Judicial ruling in general shows a mix between reality and law, one aspect of which is more apparent than the other, whether the legal aspect or the real side.

In order to distinguish reality from the law it is necessary to follow the steps of the trial Judge in his ruling, in which he dealt with the issue by distinguishing between reality and law to assure that the facts of the case were verified and to find legal adaptation that suits the facts of the case to be properly applied to his findings.

\section{The Extent to Which the Concept of Reality and Law Is Defined in Civil Cases}

The legal necessity requires the disclosure of the concept of reality and law, since it is not easy to identify and 
demystify the concept of reality in order to reach a result that enables us to reach a separation between what is the reality and what is the law, and therefore determine the jurisdiction of the Court of Cassation to consider the dispute before it ${ }^{1}$, It is noted that the parties to the dispute have submitted the dispute to the court by presenting the disputed facts with overlapping ideas without having a reason to do so, or attempting to show the ambiguous contradiction between the facts of the case and the reality and what is the law. Revealing the contradiction has contributed to the existence of ideas which are not clear and overlapping with each other, which led to the separation between what is the reality and what is the law, and in practice before the Court of Cassation there is no basis for the idea of separation only in theory, knowing that the jurisdiction of the Court of Cassation as a civil concluding To adjudicate the issue, Which cannot be defined as deficient in legislation, which led the jurisprudential to resort to judicial principles and to use them to define the concept of reality and law without adopting a certain standard to follow as an example 2 .

\subsection{Essence of Reality}

The civil action shall be based on the existence of the material facts in the matter to be presented to the court with the legal provisions. The court shall have the idea drawn from the facts and the arguments presented in addition to the evidence that proves these facts.

Therefore, the basis of the lawsuit is the presence or the absence of the facts of this matter, and the facts are the basic and the essential component of the lawsuit in the civil procedure law (procedural law) in which the case begins and gives the judge authority to deal with the case ${ }^{3}$, As in substantive law ${ }^{4}$, The jurists agree that the source of the obligation came from the case and the judicial jurisdiction came from the provisions of the Civil Procedure Law, and the substantive law that governs the matter before the court with all its elements and removes the generalization from the text as applicable, which can be considered a special text. Accordingly, the case before the Court (facts) is subject to procedural and substantive law in an orderly manner, as well as the jurisdiction of the Court and the procedures to be followed by the litigants, the burden of proof is on the litigants ${ }^{5}$, the judge applies the law by himself ${ }^{6}$.

According to some jurists of substantive law $^{7}$, that facts are the source of legal ties, whether natural or optional, optional facts may be material or legal acts, and legal acts may be issued by one or both sides, and the consequences of these actions and facts the legal effects determined by the law ${ }^{8}$.

As some jurists see in the Code of Civil Procedure ${ }^{9}$ that the facts are the expression of everything that has changed from a legal position that was originally in existence and law ranked them legal effects, that is, they have become a new legal status that have different legal effects than it had before.

Consequently, facts are not considered a source of legal effects, but rather a reason for the existence of such effects, and therefore, facts cannot be considered as a source of origin or expiration of the right. Therefore, the difference of views in the analysis of facts between the interpretative law of the substantive and procedural lies in the philosophy of thought that belongs to it. When the judge applies the substantive law to the dispute before

\footnotetext{
${ }^{1}$ Al-Qasas, A'id Muhammad, Al-Wasit in explaining the Civil and Commercial Procedures Law, Second Edition, Dar al-Ketub, Cairo, 2010, p. 1150. http://raffy.me/books/view_book/169509.

${ }^{2}$ Rigaux, Lanaturedu Controle de La de Cassation, Bruxelles, 1966, N50.76.Nouveau Code de Procedure Civile, Dalloze 2002, p.334. https://doi.org/10.1017/S0165070X00001686

${ }^{3}$ Ibrahim, Mohamed Mahmoud, The General Theory in the Legal Adaptation of the Case in the Law of Pleadings,Arab Thought House, Cairo, 1982, p 221. https://www.neelwafurat.com/itempage.aspx?id=egb28698-5028725\&search=books

${ }^{4}$ Al-Sanhouri, Abdul Razzaq Ahmad, Al-Waseet in explaining the Civil Code, Volume I, C1, Halabi Rights Publications, I 3, Beirut, 2000, p 142. https://www.law-arab.com/2015/02/Mediator-to-explain-civil-law-AbdulRazzaq-Sanhuri-pdf.html

${ }^{5}$ Al-Sharqawi, Jamil, Evidence in Civil Subjects, Dar al-Nahda al-Arabiya, Cairo, 1976, p 23. http://www.biruni.tn/cgibin/gw_2009_4_3/ chameleon? sessionid $=2011101519434428426 \&$ skin $=$ catalog.universitaire\&lng $=$ en\&inst $=$ consortium\&host $=41.229 .250 .19 \% 2 \mathrm{~B} 1111 \% 2 \mathrm{BDE}$ FAULT\&patronhost=41.229.250.19\%201111\%20DEFAULT\&searchid=10\&sourcescreen=PREVPAGE\&pos=1\&itempos=1\&rootsearch=FR EEFORM\& function=INITREQ\&search=AUTHID\&authid=963019\&authidu=1003

${ }^{6}$ Omar, Nabil Ismail, The Mediator in Challenging the Revocation of Civil and Commercial Materials, New University Publishing House, Alexandria, 2011, p 110. http://ibrary.philadelphia.edu.jo/scripts/minisa.dll/144/LIBCATA/AR_DETAIL/ACCESSION_NUMBER+\%20265 $38 \% 20$ ?SESSIONSEARCH

${ }^{7}$ Al-Sanhoori, Abdel-Razzaq, Al-Waseet in explaining the Civil Law, C / 1, Vol.I, 3, Halabi Publications, Beirut, 2000 , p 142.

${ }^{8}$ Maliji, Ahmed, Encyclopedia of the appeal of judgments, appeal against the veto, the National Center for Legal Issuances, C4, Cairo, 2005, p 831. https://library.asu.edu.bh/asu6.0/Libraries/start.aspx?fn=ApplySearch\&ScopeID=\&criteria1 $=2 . \& S e a r c h T e x t 1=0 \mathrm{D} 8 \% \mathrm{~A} 7 \% \mathrm{D} 8 \% \mathrm{AD} \%$ D9\%85\%D8\%AF+\%D9\%85\%D9\%84\%D9\%8A\%D8\%AC \%D9\%8A+

${ }^{9}$ Waly, Fathi-Zaghloul, Ahmed Maher, Theory of invalidity in the Code of Pleadings, Dar al-Nahdha Arab Publishing and Distribution, 1997, p 86. http://www.daralnahda.com/
} 
him, he shall apply it in accordance with the power vested in him by the law of civil proceedings ${ }^{10}$.

The civil action, in accordance with the provisions of Article 56/6 of the Jordanian Civil Procedure Law, includes "the facts of the case and its bonds, the plaintiff's requests" ${ }^{11}$. Accordingly, the Jordanian legislator in this text has defined the reality in the civil case, as did the Egyptian legislator in Article 63, paragraph 6 of the Egyptian Welfare Law No. 13 of 1986 and its amendments, contrary to the French legislator in paragraph 1 of Article 4 of the Act Proceedings No. 1123 of $1975^{12}$.

The allegations contained in the requests of the plaintiff and the defendants have been provided in Article 30 of the French Lift Draft Act ${ }^{13}$.

Based on the analysis of the above-mentioned texts, it is found that both the Jordanian and Egyptian legislators have dealt with the facts presented by the plaintiff to the court and did not address the defendant's progress, knowing that each lawsuit has two parties, the plaintiff and the defendant.

And thus the role of the parties to the civil lawsuit in relation to the facts in line with the provisions of the law to submit the case, including the specific facts specifically denied ignorance and display clearly ${ }^{14}$, In order for the incident to be a product of the case, it must be specific, clear and reliable, and some law scholars call it a legal event ${ }^{15}$.

In order to justify the meaning when describing the reality of law, it is understood that the law is the engine of the event without it does not move, otherwise we are considered in a situation in which we cannot distinguish between what is the reality and what is the law, and be in a state of ambiguity and illusion, Furthermore, What can be reached as a result in the differentiation between them, and some scholars believe that it is sufficient to use evidence of the incident without going to call it the law ${ }^{16}$.

The burden of proving the facts lies with the parties to the civil action and does not require them to prove the law because the proof lies with the judge ${ }^{17}$, or proof of famous facts ${ }^{18}$.

Also the legal evidence does not need to prove to those who decided to benefit from it, but to dispense with any method of proof ${ }^{19}$, The burden of proof could be reversed from one party to the other party in the proceedings, as well as the use of the so-called presumption of presumption which intervenes or excludes one of the facts mentioned in the case ${ }^{20}$.

Therefore, the Court shall not have a role in the amendment or cancellation of the facts mentioned in the case

\footnotetext{
${ }^{10}$ Sawi, Ahmed Al Sayed, Waseet in explaining the law of civil and commercial ports amended by Law No. 6 of 2007, House of Arab Renaissance, Cairo, 2011, p1126. http://bit.ly/2D5rxZg

${ }^{11}$ Jrdan Law of Civil Procedure No. 24 of 1988 and its Amendments, and Look at Decision of the Jordanian Court No. 8469 of 2018 published on the website of Qistas www.qistas.com.

https://www.jba.org.jo/BarLawSystem/LawAndSystem.aspx

${ }^{12}$ Art 4/1L'objet du litigeestdéterminé par les prétentionsrespectives des parties. https://www.codes-et-lois.fr/code-de-procedure-civile/tocdispositions-communes-toutes-juridictions-dispositions-limi-ca9638d-texte-integral

Cesprétentionssontfixées par l'acteintroductifd'instanceet par les conclusions endéfense.Toutefoisl'objet du litigepeutêtremodifié par des demandesincidenteslorsquecelles-ci se rattachent aux prétentionsoriginaires par un lien suffisant.

Look at the details in French law number: -

Décret $n^{\circ}$ 75-1123 du 5 décembre 1975 instituant un nouveau code de procédurecivile Le nouveau code de procédurecivile et son annexe font l'objetd'une publication spéciale (C.P.C. 1 à 60) annexée au Journal officiel de ce jour.

${ }^{13}$ Art 30: L'actionest le droit, pour l'auteurd'uneprétention, d'être entendu sur le fond de celle-ci afin que le juge la disebienou mal fondée.Pourl'adversaire, l'actionest le droit de discuter le bien-fondé de cetteprétention.Liensrelatifs à cetarticleCodifiépar:Décret 75-1123 1975-12-05 JORF 9 décembre 1975 rectificatif JORF 27 janvier 1976.

${ }^{14}$ Al-Saawi, Ahmad Al-Sayed, Al-Waseet in explaining the Civil and Commercial Procedures Law, Dar Al-Nahda Al-Arabia, Cairo, 2000, p 572. http://www.daralnahda.com/

${ }^{15}$ Ibrahim, Mohamed Mahmoud, The General Theory of the Legal Adaptation of the Case in the Law of Pleadings, Arab Thought House, Cairo, 1982, p. 251. https://www.neelwafurat.com/itempage.aspx?id=egb28698-5028725\&search=books

16 Auji, Mustafa, Civil Law - Part II - Civil Liability, Halabi Rights Publications, Third Edition, p. 6. https://www.neelwafurat.com/itempage.aspx?id=lbb313224-303264\&search=books. https://www.neelwafurat.com/itempage.aspx?id=egb28698-5028725\&search=books

17 Al-Sharqawi, Jamil, Evidence in Civil Law, p 23, (Ibid)

${ }_{18}$ Al-Sawy, Ahmad Al-Sayed, Al-Waseet in explaining the Civil and Commercial Procedures Law, Cit., P. 133, (Ibid).

19 Mansour, Anis Mansour Al-Mansour, Explanation of the provisions of the Jordanian Evidence Law, in accordance with the latest amendments, for the publication and distribution, 3rd edition, Amman, 2013, p. 266. www.ithraajo.com

${ }^{20}$ Sultan, Anwar, Rules of Evidence in Civil and Commercial Materials, New University Publishing House, 2005, p. 121. http://www.darggalex.com/
} 
law at all, and it cannot rule more than the adversaries requested or did not prove in the documents of the case $\mathrm{e}^{21}$.

The court shall comply with the demands of the litigants in the final motions, and the facts of the case, which are basically valid for the prosecution shall be productive, otherwise the judgment thereof shall be subject to appeal $^{22}$.

The exclusion of certain elements of the incident or the presumption of its existence is not considered an intervention by the judge in the facts of the case, rather is considered to be the core of his competence in determining the produced or unproduced facts, and this is not interference from the judge as one of the persons of proof and the status of the litigants in the case and independence and neutrality as a judge ${ }^{23}$, But is based on a legal basis of evidence aimed at showing the truth that is considered a law, that is why the work of the judge is restricted by legal provisions that governs him not by his personal knowledge in accordance with the Evidence Act, which determined the facts considered to be valid over others ${ }^{24}$, The judge can rely on facts in the case that were not exposed by the litigants in particular during the hearing of the case and were not upheld by them to prove their claim ${ }^{25}$.

The litigants shall have the right to prove their claim by the testimony of the witnesses if the facts to be proved are permitted by the law to prove them by personal evidence. Therefore, it is necessary to determine the facts to be proved by the adversary for each individual witness ${ }^{26}$, it is also possible that the case may require further elaboration of the facts or that the evidence provided is insufficient to prove it, in order to enforce the rule of $\operatorname{law}^{27}$. The judge has the right in some laws to call any witness to hear his testimony, to be productive in the case to show the truth and to achieve justice ${ }^{28}$.

If the testimony of the witness leads to the confirmation of new facts not provoked by the litigants, the court has the absolute power not to restrict the facts of the case to which the litigants have requested proof of personal evidence, that is, it can rely on the new facts in forming its conviction. In a fashion drawn by law ${ }^{29}$, the court must allow the litigants to discuss the witness and the new facts in line with the right of defense protected by the law, which gives them the right to defend and to view the foregoing against them and respect for the principle of confrontation $^{30}$. In contrast to the Jordanian legislator only limited the right to request the hearing of witnesses against the litigants, and did not give the court this right as stipulated in Article 57 of the Jordanian Civil Procedure Law ${ }^{31}$.

\subsection{Essence of Law}

The law is a set of general and abstract rules that govern conduct of the individuals in the society and which are accompanied by a physical sanction and impose public authority to respect it, even by force $\mathrm{e}^{32}$, the legal rule is

21 Aboudi, Abbas, Explanation of the Code of Civil Procedure, House of Culture for publication and distribution, 2009, p. 388, http://www.daralthaqafa.com. Hindi. Ahmed, Judgments of the Court of Cassation and its impact, New University Publishing House, Alexandria, 2006, 230. http://www.darggalex.com/.

${ }^{22}$ Khater, Talaat Yusuf, Theory of Absence in the Civil Procedure Law, House of Thought and Law for Publishing and Distribution, 2014, p. 57. https://www.neelwafurat.com/itempage.aspx?id=egb198208-5211381\&search=books

23 Mansour, Anis Mansour Al-Mansour, p 33 (Ibid).

24 Ibid, P 230,

25 Le juge ne peut fonder sadécision sur des faits qui ne sont pas dans le débat.Parmi les éléments du débat, le jugepeutprendreenconsidérationmême les faits que les parties n'auraient pas spécialementinvoqués au soutien de leursprétentions. Liens relatifs à cet article Cité par: Décret n²013-547 du 26 juin 2013 - art. 4, v. init.Codifié par: Décret 75-1123 1975-12-05 JORF 9 décembre 1975 rectificatif JORF 27 janvier 1976. https:/www.legifrance.gouv.fr/affichCodeArticle.do;jsessionid=73CFFDC5A26CC7DFEF658FD78 3F87773.tplgfr29s_2?idArticle=LEGIARTI000006410118\&cidTexte=LEGITEXT000006070680\&dateTexte $=20180605 \&$ categorieLien $=$ id \&oldAction $=\& n b \bar{R}$ esultRech $=$

${ }^{26}$ Look at Article 28/3 of the Jordanian Evidence Act of 1952 and the provisions of Article 59 of the Jordanian Civil and Look at Decision of the Jordanian Court No. 451 of 2019 published on the website of Qistas www.qistas.com.

Procedure Law No. 24 of 1988 and its amendments. Mansour, Anis Mansour Al-Mansour, P. 187 (Ibid).

${ }^{27}$ Omar, Nabil Ismail, P. 257 (Ibid).

28 Look at Article 81 of the Iraqi Code of Evidence No. $107 \quad$ of 1979 . http://iraqld.hjc.iq:8080/LoadLawBook.aspx?page=1\&SC=160120068365854

${ }^{29}$ hindi, Ahmed, P. 231, (Ibid). Look at Article 127 and 131 of the Iraqi Evidence Law No. 107 of 1979.

${ }^{30}$ Abu Al-Wafa, Ahmed, Civil and Commercial Bridges under the New Law of Pleadings No. 13 of 1968 and the Law of Evidence No. 25 of 1968, Encyclopedia of Knowledge, Alexandria, edition 14, 1986, p. 58, Hosny, Hosny Studies, Cairo, 2005 , p 9. https://books-library.online/d-673-download

31 Look at Article 57 of the Jordanian Civil Procedure Law No. 24 of 1988 and its amendments. Anis Al-Mansour,, P. 187 (Ibid), and Look at Decision of the Jordanian Court No. 451 of 2019 published on the website of Qistas www.qistas.com.

32 Dasouki, Mohamed Ibrahim, The General Theory of Law and the Right to Libyan Law, University of Qayouns Publications, edition 2nd, 
the component of the law and does not necessarily correspond to the term legal provision and may be in a legal framework provided for, or may be customary rule, or may be derived from another legal source ${ }^{33}$.

The Jordanian Civil Procedure Law did not specify the meaning of the law, but the Jordanian Civil Code provided for in Article 2 of this law. The judge knows the law in accordance with the principles of the law and is obliged to implement it without being required to apply it by the litigants ${ }^{34}$, in order for the judge not to be a denier of justice, the legislator has created legal sources that he must follow according to what it has arranged for him in order, this means that, he searches one of them and follows the other until he finds the ruling on the dispute before him $^{35}$.

Therefore, the legal rule in all its components is not a matter of reality. It may be that the original came from the legislator's conception of such a situation, abstract as a model in which he wanted to rule on a matter that could be disputed and governed by this rule. The legal basis, as soon as it is promulgated, published and enforced, has been considered separated from the reality that came from it and its existence has been acquired to become compulsory, general and abstract and to belong to it. The generalization and abstraction are two sides of one $\operatorname{coin}^{36}$, and aims to address people in their own qualities and not to the fact or facts alone, but the conditions determined by the letter ${ }^{37}$.

In light of the above, it became clear that the judge is the legal expert who applies the law without assigning the litigants or their agents to submit the legal texts that govern the issues presented and agreed with their requests to resolve the dispute ${ }^{38}$. The judge does not delegate his powers and authorities to third parties to find the legal texts governing the dispute before him, although he can rely on certain specialized experts to express their opinion on his specific technical matters, and this does not constitute a waiver of his legaluthorities ${ }^{39}$.

The judge is obliged to search for the legal basis that is fully applicable to the dispute presented and governed by it, and due for application, and it does not matter what is said about the multiplicity of legal provisions or their abundance, ambiguity or the absence of a text that governs to dispose of this duty ${ }^{40}$. The judge also should have the certain knowledge about what the legal rule contains and its interpretation according to legal methods to reach the wisdom of legislation ${ }^{41}$.

In light of the foregoing, the litigants shall be submitted to the Registry of the facts, attributions and requests of the Registry, and shall not be bound by the legal basis governing these facts ${ }^{42}$. The Court shall accept this lawsuit without modifying its elements represented in the reason ${ }^{43}$. The determination of the dispute before it in accordance with the provisions of the law, and the determination of the appropriate legal description of the case is in accordance with the facts of the case law, without restricting the legal adaptation of the case to the parties is considered a non-binding movement by the parties ${ }^{44}$. The judge has defined the procedural roles between him and the litigants in the civil case ${ }^{45}$. Therefore, we must address the commanding and complementary legal rules in order to determine the scope of the judge's obligation. Some rules of the Civil Procedure Code are complementary, In other words, that these rules are not related to public order, such as the relative formality defenses $^{46}$, spatial jurisdiction ${ }^{47}$.

1989, pp. 13-15. Abdel-MoneimFarag Al-Sadda, Origins of Law, Al-Ma'aref Establishment, Alexandria, 1994, pp. 11-14. https://books.google.jo/books?id=jEeOQgAACAAJ

${ }^{33} \mathrm{Al}-\mathrm{Zu}$ 'bi, Awad Ahmad, Introduction to the Law of Law science, Enrichment for Publishing and Distribution, Amman, edition 4th, 2017, p. 164. http://link.qnl.qa/resource/jVvuABs1ywY/

${ }^{34}$ Jordanian Civil Law No. 43 of 1976.

${ }^{35} \mathrm{Al}-\mathrm{Zu}$ 'bi, Awad Ahmad, Introduction to Law, p 96, ibid.

${ }^{36}$ Al-Sadada, A.-M. F. Origins of Law, Al-Ma'aref Establishment, Alexandria, 1994, p 16. https://books-library.online/d-673-download

${ }^{37}$ Al-Douri, Ghalib, The Introduction to Law, especially the Jordanian, Irbid, Hammad Center, edition 4th, $p$ 12. ). https://www.neelwafurat.com/itempage.aspx?id=lbb116366-76528\&search=books

${ }^{38}$ Omar, Nabil Ismail, P 110 (Ibid).

${ }^{39}$ Look at Article 83 of the Jordanian Civil Procedure Law No. 24 of 1988 and its amendments.

${ }^{40} \mathrm{Al}-\mathrm{Zu}$ 'bi, Awad Ahmad, P 100 (Ibid).

${ }^{41}$ Ibid, p 100.

${ }^{42}$ Look at Article 56 of the Jordanian Civil Procedure Law No. 24 of 1988 and its amendments.

${ }^{43}$ Abu Al-Wafa, A. Arbitration in Arab Laws, Origin of Knowledge, Alexandria, p. 22.

${ }^{44}$ Abu Al-Wafa, A. The Theory of Judgments in the Code of Pleadings, Alexandria, Al-Ma'aref Establishment, edition 5th, $1985, \mathrm{p} 271$.

${ }^{45}$ Ibid p 271.

${ }^{46}$ Bakri, Abdelkader, and Bashir, Zuhair, Introduction to the study of law, the Higher Education Press, Mosul, 1989, p. 108. http://www.iraqnla-iq.com/opac/fullrecr.php?nid=37415\&hl=ara. Aboudi, Abbas, p 279 (Ibid). 
The judge is obliged to apply the custom to his own initiative, if he does not find a provision in the legislation to be considered and recognized as one of the sources of the legal norm ${ }^{48}$, is not considered an intervening in the facts $^{49}$. The customary rule may at times be unknown and unclear, and it is difficult to ascertain its merits. In this case, the judge may ask the opponent whose alleged existence to establish the evidence ${ }^{50}$.

In light of the foregoing as mentioned previously, it is clear that the question of reality and the law is purely theoretical. The attempt to distinguish between the two is possible. The adversaries have absolute power over the facts of the case and the power of the judge according to the law address the case and his knowledge of the legal rules and his ability to bring down the facts of the dispute to resolve it ${ }^{51}$.

Based on the above opinions, the researcher believes that the distinction between the facts and the law in practice may show difficulties starting from writing the case list to the decision that will resolve the dispute through all the stages of the case due to the deficiency in the Jordanian Civil Procedure Law, In contrast to the French legislature, which defined the authorities of the judge and the adversaries to distinguish between the facts and the law. It stipulated that the judge has to ask the litigants to present the reality, and in turn he provides the appropriate legal texts about the facts ${ }^{52}$.

Referring to the French Code of Procedure No. 1123-75 of 5 December 1975, it appears that the legislator organized this matter technically, determining the jurisdiction of the court and the adversaries in terms of facts and law trying to determine what the reality is and what is the law, he defined the role of litigants fact and law.

The judge fulfills the public interest in applying the law while the parties seek to achieve their own interest, that is, the distribution of the law roles between them, the prosecution is the plaintiff who filed the lawsuit and claimed disputed facts he has the burden of proving the claim and the defendant did not deliver what the plaintiff claimed in application of the beginning of ownership of the dispute in accordance with the text Articles 1 and 2 of the French Code of Procedure ${ }^{53}$, the litigants have the right to initiate or terminate a case before a judgment is rendered in which the dispute is resolved or in accordance with the provisions of the law, and the proceedings are well served ${ }^{54}$.

The French legislator has dealt with the issues of reality (Les Faits) in the following articles, where article 6 provides for the power of the litigants to submit the facts produced in the case. The claim of a list made by the plaintiff contains what he claims and the defendant provides his answer, and the facts produced are the abstract reasons devoid of legal and subsidized adaptation with evidence ${ }^{55}$, and provided that the judge is not entitled to judge by his personal knowledge or facts that were not presented in the list of the case and discussed by the litigants in Article $7 / 1^{56}$, the second paragraph of Article 7 stipulated the right of the judge to take some facts that came in the context of the case and That is, the judge has some kind of authority over the facts that have been discussed during the course of the case and have not been adhered to by the litigants and may have been productive in the chapter of the dispute ${ }^{57}$. Article 8 of the judge shall ask the litigants to extend their claim and explain the ambiguity to be resolved ${ }^{58}$.

The French legislator has dealt with the issues of law in articles 12 and 13 of the annexes law. Article 12 of the law stipulates the task from the judge in the application of the law. In some of the paragraphs, this article included some of the powers of the litigants. In accordance with the provisions of the law, so that the litigants are not obliged to submit the provisions of the law governing what they claim, and in the second part the judge will

\footnotetext{
${ }^{47}$ Aboudi, Abbas, P. 154 (Ibid).

${ }^{48}$ Al-Zu'bi, Awad Ahmad, P. 164, (Ibid).

${ }^{49}$ Ibid p 145.

${ }^{50}$ Tawfiq Hassan Faraj, Introduction to Legal Sciences: General Theory of Law, University House, Beirut, 1988, p. 258. http://www.philadelphia.edu.jo/newlibrary/2014-11-24-13-12-11/580-2014-11-23-15-59-31/88455-26908

${ }^{51}$ Aboudi, Abbas, P. 184, (Ibid).

${ }^{52}$ French Code of Procedure No. 1123-75, 5/12/1975.

${ }^{53}$ Art 1 "Seules les partiesintroduisentl'instance, hors les casoù la loien dispose autrement. Ellesont la libertéd'ymettre fin avantqu'elle ne s'éteigne par l'effet du jugementouenvertu de la loi",etArt2" Les parties conduisentl'instance sous les charges qui leurincombent. Il leurappartientd'accomplir les actes de la procéduredans les formes et délaisrequis"

${ }^{54}$ Art 3 "Le jugeveille au bon déroulement de l'instance ;il a le pouvoird'impartir les délais et d'ordonner les mesures necessaries".

${ }^{55}$ Art 6 "Al'appui de leursprétentions, les parties ont la charge d'alléguer les faitspropres à les fonder".

${ }^{56}$ Art 7 "Le juge ne peut fonder sadécision sur des faits qui ne sont pas dans le débat".

${ }^{57}$ Art 7 "Parmi les éléments du débat, le jugepeutprendreenconsidérationmême les faits que les parties n'auraient pas spécialementinvoqués au soutien de leurs pretentions".

${ }^{58} \mathrm{Art} 8$ "Le jugepeut inviter les parties à fournir les explications de fait qu'ilestimenécessaires à la solution du litige".
} 
adapt the case before him based on the facts provided by the adversaries carefully because the mistake in the adjustment entails a wrong application in the ruling requiring the repeal, The judge is obliged to pronounce This, it is not an interference of the judge in the facts, and the third part presents the facts and the judge sets the appropriate texts to apply them to the facts, regardless of what the litigants have provided for the legal adaptation of the facts ${ }^{59}$. In light of this and what is stated in the text of article 16 Of the French Bridge Act, which allows adversaries to discuss what the judge may judge and to reconcile this article with the former part of article 12 , finds that the judge cannot judge on the basis of what has been adapted by himself, without confrontation between the adversaries ${ }^{60}$.

Article 4 of paragraph 12 stipulates that if the parties have the right to dispose of it on a legal basis or agreed upon by the parties, the judge cannot change it. Thus, the parties may restrict the judge to this adjustment and determine the law applicable to the dispute to settle it. Applicable to such facts, such power conferred on the parties to the violation of the legal text will lead to the wrong application of the law.

Article 12, paragraph 5, also provides for the right of parties to resort to the alternative way of settling disputes rather than resorting to the natural way (the court) in order to create a balance between the judge and the parties to the conflict within the scope of the law.

Accordingly, the French legislator, in article 12, paragraphs 1, 2 and 3, of the Code of Plea, gave the judge absolute authority within the scope of the law and contradicted in paragraphs 4 and 5 of the same article which freed the litigants from this obligation and provided that the law is not Exclusive to the judge.

Article 1362 of the French Code of Procedure states that the judge has the right to ask the parties to submit their observations on the texts of the law that he wishes to apply to the facts that are necessary for the resolution of the dispute, in accordance with the aforementioned article 8, the place talks about the law.

\section{The Jurisdiction of the Court of Cassation Shall Be Held in Accordance With Reality and Law}

The Court of Cassation is the highest judicial body in the State. It is responsible for monitoring the integrity of the application of the law and does not consider as third degree of litigation. It does not have jurisdiction to look into the facts, rather its role is limited only to examine the contested judgment from the legal side, thus determining its role only on the good application of the law and interpretation in order to stabilize the legal principles and unite them between all courts.

The jurisdiction of the Court of Cassation in the civil case shall be held by examining the appeals submitted to it as a court of law, which is the primary function of the court as a court of appeal by observing the validity of the application of the law and reviewing the integrity of the procedures followed by the court of the subject during its consideration of the case and issuing its decision. The security of the adversaries to establish justice and equality preserving the unity of legislation ${ }^{61}$.

Court of Cassation has a very important role in establishing, consolidating and stabilizing legal principles, which can be consulted and guided in cases before the courts, especially in complex legal matters, to find a proper application of the legal norm and to rely on it for similar cases that may be brought before the courts. The law was applied in a different manner and appealed in front of it $^{62}$.

Court of Cassation is not considered as a third degree of litigation and is a court of law in the civil judiciary ${ }^{63}$, the last resort to the litigants in terms of proper application of the law. The function of the Court of Cassation is to analyze the legal texts and to unite the views of the judiciary Understand and apply legal texts.

\footnotetext{
${ }^{59}$ Art 12 "Le juge tranche le litigeconformément aux règles de droit qui luisontapplicables. Ildoit donner ourestituerleurexacte qualification aux faitsetacteslitigieux sans s'arrêter à la dénomination que les parties enauraientproposée. Toutefois, il ne peut changer la dénominationou le fondementjuridiquelorsque les parties, envertu d'un accord exprès et pour les droits dontellesont la libre disposition, l'ontlié par les qualifications et points de droit auxquelsellesentendent limiter le débat...”.

${ }^{60}$ Art 16 "Le jugedoit, entoutescirconstances, faire observer et observer lui-même le principe de la contradiction.Il ne peutretenir, danssadécision, les moyens, les explications et les documents invoquésouproduits par les parties que sicelles-ci ontété à mêmed'en -débattrecontradictoirement. Il ne peut fonder sadécision sur les moyens de droit qu'il a relevésd'office sans avoir au préalableinvité les parties à présenterleurs observations.

${ }^{61}$ Aboudi, Abbas, Rules and Pleadings, Sharif, Dar al-Senhuri Legal and Political Science, Iraq, 2015, p. 418. Sharif, Hamed, Criminal Cassation, An Applied and Analytical Study of the Law of Challenging the Denunciation of Criminal Proceedings, University Thought House, Alexandria, 1999, p. 49. http://dfgpublish.com/

62 Saif, Ramzi, al-Waseet in explaining the law of pleadings, Dar al-Nahda al-Arabiya, edition 7th, Cairo, 1970, p165. http://www.daralnahda.com/

${ }^{63}$ Aboudi, Abbas, P 11, (Ipid)
} 
The Court of Cassation shall appeal the judgment for its violation of the law in application and interpretation. It shall establish a list of cassations on the grounds for contesting the contested judgment in the legal sense, and no control of the Court of Cassation on the facts of the case ${ }^{64}$, that the Court of Cassation considers and settles the appeal submitted to it in legal terms.

Therefore, there is a single court of cassation in the state and the multiplicity of bodies are for practical necessity. It is unreasonable to have a number of courts in the state to cassata, because in this confusion of work and finding multiple directions will certainly contribute to the multiplicity of legal principles, and does not achieve Unity for Judiciary and Law ${ }^{65}$.

This leads us to ask the following question: Does the Court of Cassation consider a supreme judicial body to consider judicial decisions legally or is it a third degree of litigation? It is not easy to answer the question because the determination of the jurisdiction of the Court of Cassation depends on the procedural effect of reality and the law. If the Court of Cassation is considered a supreme court of law, its jurisdiction shall be subject only to considering the legally contested judgments and has no authority to examine the facts. The litigation shall be subject to a review of the facts of the case and the ruling on the subject matter of the dispute if appealed.

The French legislator settled the matter in Article 604 of the Code of Pleadings as a Supreme Court to review the verdicts in relation to the violation of the $\operatorname{law}^{66}$, whereas the facts are not examined because they are within the jurisdiction of the Court of the subject and the reasons for the veto should be focused on violating the law without the facts. The matter has to do with the interpretation of the law. Court of Cassation has been prohibited from dealing with it, since it is within the jurisdiction of the legislative authority ${ }^{67}$, and it does not have recourse to the power of legislation to issue an interpretative law in a vague and unclear matter in the case before it. The legal principles of the French Court of Cassation are not binding on the courts because they are not a law and their violation is not grounds for appeal, although the decisions of Court of Cassation have literary power and do not rise to the rank of law. Therefore, the judge may violate a principle of the legal principles issued by the Court of Cassation, and may adopt a decision of a lower court and refutes a previous decision if he finds that this principle deserves consideration $^{68}$.

The Jordanian legislator is much closer to the French legislator than he has been in this matter. The reasons for the appeal must be based on the violation of the law in the contested decision, which shows that the Court of Cassation in civil cases does not discuss the reasons for the appeal ${ }^{69}$.The Jordanian legislator has also allowed the Court of Cassation to face the facts and to rule on the matter when the subject is valid for judgment without returning it to the court of matter on which the subject was previously presented and in which it was ruled contrary to the provisions of the French legislature ${ }^{70}$.

\subsection{Court of Cassation Shall Be Considered as a Supreme Judicial Body to View the Judgments}

The appeal in the manner of cassation before Court of Cassation shall be regarded as an exceptional way of examining the judgments of courts of appeal (court of the subject) and shall investigate the violation of the law. It is not permissible to appeal against all the rulings of Court of Appeal, but rather according to the provisions of the legislator and exclusively in Article 191 of the Jordanian Civil Procedure Law ${ }^{71}$.

Accordingly, the challenge appeal by cassation discrimination does not allow the adversaries to submit their case again and objectively before Court of Cassation, and it is not permitted to provide new evidence for the first time before it has not been submitted before the Court of the matter ${ }^{72}$. In light of the above, separating between the

\footnotetext{
${ }^{64}$ Omar, Nabil Ismail, P 460, (Ibid).

${ }^{65}$ Al-Akhras, NashatAbdul Rahman, Explanation of Civil Procedure, Dar Al-Thaqafa for Publishing and Distribution, edition 2nd, Amman, 2010, p 67. http://www.daralthaqafa.com/DefaultAr.aspx

${ }^{66}$ Art 604 "Le pourvoiencassation tend à faire censurer par la Cour de cassation la non-conformité du jugementqu'ilattaque aux règles de droit”.Modifié par Décret 79-941 1979-11-07 art. 2 JORF 9 novembre 1979 envigueur le 1 janvier 1980.

${ }^{67}$ Abdul Wahab, Abdul Razzaq, challenging the provisions of discrimination in the law of civil lifts, Dar al-Hikma for printing and publishing, Baghdad, 1991, p 305. http://www.daralnahda.com/

${ }^{68}$ Omar, Nabil Ismai, P 720, (Ibid).

${ }^{69}$ Shoshari, Salahuddin, Explanation of the Code of Civil Procedure, Dar Al-Thaqafa for Publishing and Distribution, edition 2nd, Amman,, 2010, p 388. http://www.daralthaqafa.com/DefaultAr.aspx

${ }^{70}$ Aboudi, Abbas, 2009, p. 387, (Ibid).

${ }^{71}$ Jordanian Civil Procedure Law No. 24 of 1988 and its amendments and Look at Decision of the Jordanian Court No. 3558 and 62 of 2019 published on the website of Qistas www.qistas.com.

72 Aboudi, Abbas, 2009, p 427, (Ibid).
} 
facts and the law ${ }^{73}$, Court of Cassation is a supreme court of law and it is not a third degree of litigation. Its jurisdiction is to consider the contested decision in legal terms only without considering the facts. The Court of Cassation is a court of law which is responsible for properly monitoring the application of the law and its explanation in accordance with the law.

The Jordanian legislator, in Article 198 of the Jordanian Civil Trials Law, stipulates the conditions in which the provisions are distinguished by six reasons as follows ${ }^{74}$ :

1. If the contested judgment is based on a violation of the law or an error in its application or interpretation ${ }^{75}$.

2. If there is a nullity in the judgment or a nullification of the proceedings, it shall affect the judgment ${ }^{76}$.

3. If the judgment is final, contrary to another ruling already issued between the opponents themselves without changing their qualities and the dispute is related to the same right and the case and the power of the case whether pushed or not pushed on this.

4. If the judgment has not been established on a legal basis so that its reasons do not allow Court of Cassation to exercise its control.

5. If the judgment ignored the dismissal of a claim or the judgment of something not requested by the litigants or more than they requested ${ }^{77}$.

6. If the judgment and actions taken in the case are in explicit violation of the law or the assets of the trial are a violation of the duties of court, the court of cassation shall decide to revoke it even if the privileged person does not appear in its regulations to state the reasons for the said violation. Then it shall not be a reason for the deficiency unless it is objected to in the courts of first instance and appeal. The objection was neglected and then one of the parties referred to it in his discriminatory list and it would change the face of the referee ${ }^{78}$.

In reviewing this text, the Jordanian legislator mentioned the reasons behind the error in applying the law to expand the umbrella of Court of Cassation ${ }^{79}$, and to challenge discrimination from unusual methods, it is not sufficient to challenge the loss of the appellant, but must provide one of the reasons cited by the legislator exclusively and sufficient to be available ${ }^{80}$.

Concerning the first reason: If the contested judgment is contrary to the applicable legal text, with clarity that cannot be interpreted but did not take it, and the violation in the operative sentence ${ }^{81}$, or commenting an error in the application, the judge overlooked an explicit rule of law applicable and applied The text does not apply to the facts of the case, which led to a different result of the wisdom of the text, or misinterpretation of the text in its interpretation, interpreting it out of its spirit or wisdom, which led to change in its the intended meaning ${ }^{82}$.

Therefore, the court based on this reason cannot resort to the facts, On the contrary, it must handle the facts to the court of the subject and check the text of the law applied by the court of the subject to these facts, whether it is true or not, since it is not a third degree of litigation.

Regarding the second reason, the nullification in the ruling is due to reasons that lead to nullification, such as the judge of the ruling is not the judge of deliberation or not causing the decision, and the invalidity of the procedural side of the lawsuit, which is represented in any of its actions took place during the judgment, or was his predecessor and influenced the ruling and his abolition was Discriminatory ${ }^{83}$, the acceptance of the court evidence after the declaration of the conclusion of the trial and relying on it in the judgment, which necessitates the dissolution of the decision and return the case to its source to execute the legal requirement, cannot be limited to these reasons.

\footnotetext{
${ }^{73}$ Ibid, p 116.

74 Jordanian Civil Procedure Law No. 24 of 1988 and its amendments.

${ }^{75}$ Look at Decision of the Jordanian Court No. 277 of 2019 published on the website of Qistas www.qistas.com.

${ }^{76}$ Ibid.

${ }^{77}$ Lool at Decision of the Jordanian Court No. 1197 of 2017 published on the website of Qistas www.qistas.com.

${ }^{78}$ Look at Decision of the Jordanian Court No. 2733 and 429 and 451 of 2019 published on the website of Qistas www.qistas.com.

${ }^{79}$ Aboudi, Abbas, 2009, p 422, (Ibid).

${ }^{80}$ Decision of the Jordanian Court of Cassation No. 178/84, p. 990, in 1984. http://www.jc.jo/node/3918

${ }^{81}$ Fahmi, Muhammad Hamid, Explanation of civil and commercial proceedings, 1940, item 745.

82 Ashmawi, Mahmood, Rules of Pleading in Civil and Mixed Law, Monchaat Al Maaref, Alexandria, Article 1136, Vol. 2, 1927, p 990. https://books-library.online/d-673-download

${ }^{83}$ Aboudi, Abbas, 2009, p 391, (Ibid).
} 
The nullification of the proceedings is of two types, the first of which is related to public order, which is raised by the court on its own without the demand of the adversaries, and the second is related to the rights of the adversaries, there is no reason to appeal unless asked and neglected by the court. Therefore, Court of Cassation did not consider the substantive aspect, not even the legal aspect, but considered the violation of fundamental procedures, and therefore Court of Cassation cannot be considered as a third degree of litigation.

The third reason is the contradiction of the provisions, that is, if a ruling is made and became irrevocable and contradicts with a previous rule between the same opponents and did not change their qualities and the dispute is related to the same right cause and place and won the power of the case being prosecuted, this reason gave the Court of Cassation power to veto the ruling without considering the facts and the law, but the defect in the ruling itself and Court of Cassation is not a third degree of litigation ${ }^{84}$.

For the fourth reason: if the judgment is not based on a legal basis, so that the reasons for which Court of Cassation does not permit it to exercise control, the legislator gave the court of mays, in this case, a mandate to rule if it was not based on a legal basis by understanding the facts of the case. To understand reality in isolation from the legal evidence, and therefore Court of Cassation is not a third degree of litigation.

As for the fifth reason: "If the arbiter fails to rule on one of the demands or rule something that the adversaries did not request or more than they requested," it is found that the legislator has provided several pictures. If the judge fails to rule on a request in the case law, To cause his ruling and mention the reasons that led him to reject or not to accept the claims or defenses of the litigants, and the texts that were adopted in his decision ${ }^{85}$, therefore his omission is considered as a claim for discrimination and his decision is flawed and presented for revocation because of a material error. The same verdict is not flawed in the case of the ill case of AloAia or law ${ }^{86}$. The second form of judgment is something that the litigants did not ask for or more than they requested ${ }^{87}$. The law requires that the case be brought up by a regulation ${ }^{88}$ and must include its subject matter and requests ${ }^{89}$. Therefore, the court and the litigants must comply with the requests in the case law. Something that the litigants did not request or ruled more than they requested. The decision is flawed. Court of Cassation has considered this defect without going to the facts or the law, and therefore the Court of Cassation does not considers a third degree of litigation.

As for the sixth reason, if the ruling and the actions taken in the case are in explicit violation of the law, or if the assets of the trial are an offense related to the duties of the court, court of cassation shall decide to revoke it even if the appealed person in his regulations does not mention the reasons for the said violation.

However, if the violation is related to the rights of the adversaries, then there is no reason for the repeal, unless it is objected in the Courts of First Instance and Appeal, and the objection is neglected and then one of the parties mentioned in its discriminatory list, which would change the status of the ruling.

Accordingly, the violation relating to the rights of the litigants shall not be grounds for revocation unless it is objected by the litigants before the court of the subject, and was disregarded and then challenged by one of the litigants in the list of discrimination which would have changed the ruling. This does not change the nature of the jurisdiction of Court of Cassation, a degree of litigation is considered.

In light of the above $\mathrm{e}^{90}$, some jurists believe that what the legislator mentioned in the text of the aforementioned article agree as a branch of one origin which is contrary to the law, and that the reasons cited are no more than pictures of violations of the law. Therefore, Not in the reasons cited by the legislator and exclusively in article 198 above, because discrimination is an unusual method of appeal, that is, if there are reasons in the list of appeal not specified by the legislator be presented for non-acceptance ${ }^{91}$, "A reason for denying the repetition of the reasons for appeal pursuant to article 193 (b) of this Law shall not be valid The principles of civil trials do not include a reason for appeal pursuant to article 198 of the said law.

Article 248 of the Egyptian Penal Code stipulates that:

\footnotetext{
${ }^{84}$ Abdulwahab, Abdul Razzaq, challenging the provisions of discrimination in the Civil Procedure Code, Baghdad edition, p 201.

${ }^{85}$ Aboudi, Abbas, 2009, p 422, (Ibid).

${ }^{86}$ Decision of the Jordanian Court of Cassation No. 751/96, p. 2946, 1997. http://www.jc.jo/decision-tmeez?page=2

${ }^{87}$ alquda, Mufleh Awad, Civil Procedure and Judicial Organization, Dar Al-Thaqafa for Publishing and Distribution, Amman, edition 2nd, 2017, p 426. http://www.daralnahda.com/

${ }^{88}$ Ibid, p 215.

${ }^{89}$ Article 56, paragraphs 5 and 6, Jordanian Civil Procedure Law

90 Alquda, Mufleh Awad, p 379, (Ibid). Abdulwahab, Abdul Razak, p 75 (Ibid).

${ }^{91}$ Decision of the Court of Cassation No. 546, 1994, No. 7000 of 2018, No. 5348 of 2018. http://www.jc.jo/decision
} 
1. If the contested judgment is based on a violation of the law or an error in application or interpretation.

2. If a nullity of the judgment or a nullification of the proceedings has affected the judgment ${ }^{92}$.

Article 249 on the separation of the court in a dispute contrary to another rule already issued between the opponents themselves and the power of the matter ordered ${ }^{93}$.

Egyptian jurisprudence considers that all the reasons stated by the Egyptian legislator mentioned in the above texts indicate that the appeal must be based on violation of the law ${ }^{94}$. Accordingly, the Egyptian Court of Cassation has jurisdiction to consider the case before it in case of violation of the law and not the reality ${ }^{95}$. Therefore, the appeal against the cassation before Court of Cassation does not allow it to take up the case again and look at understanding of the facts and their estimation in order to reach the judgment because it is not within its jurisdiction and the Court of the matter does not observe this. As it is merely a material fact that is dealt with by the trial judge in accordance with linguistic and logical criteria which are not subject to legal rules in which it is possible to make a mistake; The discrimination cannot be contested for a factual or legal reason that is involved with an incident that was not dealt with by the adversaries at a previous stage ${ }^{96}$, Of the jurisdiction of the subject judge ${ }^{97}$, and therefore the Court of Cassation does not consider a third degree of litigation.

The French legislator, in Article $604^{98}$, pleadings on the grounds for appeal, namely, if the contested decision is contrary to the law or lack of jurisdiction or to bypass authority or violation of formal procedures and if it contradicts with the provisions.

In referring to the above text, it is found unanimously that the reasons for the veto in the French law reside in its role in violating the law without the facts and for example cited by the legislator exclusively, so the jurisdiction of the French Court of Cassation control the law without exposure to facts because it is the jurisdiction of Court of subject and is not allowed to expose To interpret the text because that is within the jurisdiction of the legislature $^{99}$. If Court of Cassation finds ambiguity in the legal text applicable to the matter before it, it shall resort to the legislative authority to issue an interpretative law and shall be binding on all courts of different degrees.

Thus, the legal principles of Court of Cassation are not binding on the lower courts, since their legal system does not take precedents. Therefore, judgments of the lower courts are not subject to a veto if they violate a principle of the Court of Cassation. On the contrary, these provisions are worthy of attention in their new decision and fall back on their previous principles ${ }^{100}$, thus are not being considered a third degree of litigation.

\subsection{The Court of Cassation is a Third Degree of Litigation}

In light of the conclusion of the previous request, considering Court of Cassation, it examines the validity of law enforcement on the facts as a supreme court in the state to examine the provisions in terms of violation of the law without reality. Court of Cassation recognizes the facts as received from the court of the subject. The appellant presents his list of discrimination, in the decision made on the basis of violating the law in line with Jordanian, Egyptian and French legislation.

Therefore, the Court of Cassation does not have the right to consider the facts if it decides to nullify the decision by being a Supreme Court, if it is to return the papers to the Court of Cassation to adjudicate the case. The Court of subject has the option to follow criticism and guidance of the previous decision of Court of Cassation.

It appears that the position of the Jordanian legislature in defining the description of Court of Cassation as $\mathrm{s}$ Supreme Court or a third degree of litigation may differ from that of the Egyptian and French legislators.

Its Noted that the Jordanian legislator, after determining the reasons for the appeal in Article 198, the principles of civil trials, which cannot accept the appeal by repeal, if at least one of the reasons mentioned in the above

\footnotetext{
92 Civil and Commercial Procedural Law of the Arab Republic of Egypt No. 13 of 1986. http://www.lcrdye.org/2016/02/25/

${ }_{93}$ ibid

${ }^{94}$ Omar, Nabil Ismail, p 180, (Ibid).

${ }_{95}$ Aboudi, Abbas, p 400, (Ibid).

${ }^{96}$ Ibid p 394.

${ }^{97}$ Al-Qudah, Mufleh, p 419, (Ibid).

${ }^{98}$ Art 604 "Le pourvoiencassation tend à faire censurer par la Cour de cassation la non-conformité du jugementqu'ilattaque aux règles de droit".

99 Abdul Wahab, Abdul Razzaq, challenging the provisions of discrimination in the law of civil lifts, Dar al-Hikma for printing and publishing, Baghdad, 1991, p 305.

${ }^{100}$ Shoshari, Salahuddin, p 427, (Ibid).
} 
article, which are all related to the violation of the law, but he moved from that the text of article 197 Principles of civil trials:

1. Court of Cassation shall consider the minutes of the proceedings and the rules submitted by the parties and the other documents of the case to be examined only if it decides by itself or at the request of one of the parties, to consider them as a pleading and agreed upon that ${ }^{101}$.

2. If the Court decides to hear the case, a case shall be set for the trial and the parties shall be invited to attend it.

3.(A) On the appointed day, the Court shall commence the hearing of the case in the presence of a representative of the parties' lawyers and after hearing the arguments of the present and clarifying what it deems necessary to clarify the case and makes its decision.

3.(B). No party shall be allowed to plead before Court of Cassation except through a lawyer. If no lawyer of any panel is present at the hearing, the Court shall consider the case in light of the minutes of the trial, the regulations and the existing papers and issue its decision ${ }^{102}$.

If the court is unable to dismiss the case at the same session, it postpones its vision to another session, and whether the parties' lawyer attended the hearing or the subsequent sessions, or all or some of them failed to make their decision either by supporting the verdict or by revoking it and returning it to the court that issued it.

4. Court of cassation shall have the right to adjudicate the case without returning it to its source if the matter is valid for the judgment and the judgment it makes in this manner shall not accept objection or review ${ }^{103}$.

Therefore, by trying to reconcile the previous texts, we find that the position of the Jordanian legislator is not fixed, and it is not possible to find a specific criterion used in the description of Court of Cassation, and based on the principle of separation between the issues of reality and law and refer to the text of article $197 / 1^{104}$ of the civil assets that it considers the records of the case .....and other papers of the lawsuit, the examination of the records of the lawsuit and other documents of the case indicates that the text has been absolute and the jurisprudential rule says absolute is being released unless it is bound, therefore, Court of Cassation can consider the case as if it is related to matters of fact or law. Thus, Court of Cassation becomes court of subject, and it is inconceivable, for the difference of its function and its special status.

In addition, the provisions of paragraph 2 and 3 / a of Article 197 of civil law stipulate that: "... a day shall be set for the trial and the parties shall be invited to attend it, and ... after hearing the arguments of the present and inquiring into what "The Court of Cassation has the authority to invite the parties to the case and to hear the arguments of those who were present and ask the litigants and answer their questions. The question that arises in this regard is whether the questions that are asked about them are related to reality or the law? The answer is, of course, to the issues of reality because the duty is to clarify the issues of reality rests with the parties as a general rule that does not accept exception, and the issues of law are the jurisdiction of the court as a general principle that does not accept the exception. And that the litigants provided a legal adaptation of the case, which was not binding to the court ${ }^{105}$, Article 4, paragraph 4, of the same article, which gave Court of Cassation the power to adjudicate the matter, if it ruled that the contested judgment had been overturned in contravention of the law or that there was an error in its application or interpretation, This is considered to be a third degree of litigation. This provokes the disapproval of the form of the position of the Jordanian legislator in this text, because he withdraws from the principle of litigation on two degrees and grants this role to Court of Cassation ${ }^{106}$.

The jurisprudents of Jordanian law have unanimously agreed ${ }^{107}$ that Court of Cassation is competent to hear the case from a legal point of view as a court of law and does not rule on the matter because it is simply not a third degree of litigation, but it performs its duties by scrutinizing the case papers. The Jordanian legislator has taken an exception in this text, Granting Court of Cassation the right to adjudicate the case if its subject matter is valid for the judgment, This is done in order to simplify the proceedings of litigation before the litigants.

\footnotetext{
${ }^{101}$ Look at Decision of the Jordanian Court No. 4901 of 2018 published on the website of Qistas www.qistas.com.

${ }^{102}$ Look at Decision of the Jordanian Court No. 1736 of 2018 published on the website of Qistas www.qistas.com.

103 Jordanian Civil Procedure Law No. 24 of 1988 and its amendments, and Look at Decision of the Jordanian Court No. 8774 of 2018 published on the website of Qistas www.qistas.com.

${ }^{104}$ Look at decision of the Jordanian Court of Cassation No. 7508 of 2018 and No. 4906 of 2018 and Decision of the Jordanian court No. 6329 of 2018 published on the website of Qistas www.qista.com.

105 Al-Akhras, Nashat Abdul Rahman,, p 36, (Ibid).

106 Al-Qudah, Mufleh Awad, p 437, (Ibid), and look at Decision of the Jordanian Court No. 4922 and 3901 of 2017 published on the website of Qistas www.qista.com

107 Ibid, p 80.
} 
Therefore, the researcher sees when the ruling was annulled by Court of Cassation because of violation of the law in general, and this violation is based on a formal or substantive basis, which will result in to the point that was annulled, and therefore the case needs a resolution to resolve this dispute, Court of Cassation will continue to consider it until judgment. It must consider it from the point of annulment and re-examines it in terms of law and reality. Therefore, Court of Cassation shall be considered as a third degree of litigation.

In light of the legal provisions of the Jordanian legislator to determine the jurisdiction of Court of Cassation, it is unclear and imprecise to describe them, because using these texts we cannot reach a reliable description of them.

In accordance with the Egyptian legislation, Court of Cassation is considered the offenses referred to in the contested decision relating to the violation of the law without consideration of the facts ${ }^{108}$, as stipulated in Article 269/4 of the Egyptian Code of Procedure ${ }^{109}$, which gives Court of Cassation the right to subject matter to the dispute if the contested decision in the matter is already valid for adjudicating it or challenging the decision for the second time, in order to expedite the adjudication of cases and reduce procedure ${ }^{110}$, the legislator has been deviated from the general jurisdiction of Court of Cassation and made it a third degree of litigation.

The French legislator has defined the specialties of Court of repeal carefully in considering the contested judgment in violation of the law only ${ }^{111}$, and does not accept the challenge in the reality, and returning the case file to its source in case the decision was for fear to be far from its primary function which is the appropriate application of the law to take the legal requirement. Article 15 and 16 of the French Lift Act left Court of Cassation has the right to consider the matter and to adjudicate the case before it without sending it to its source, provided that it is valid for pronouncing the sentence ${ }^{112}$, knowing that Court of Cassation did not use this jurisdiction to monitor the application of the law.

Results of this research agree with the opinions of a group of Jordanian lawyers, retired judges, clients and legal consultants regarding the need for amendments in the functions and responsibilities of court of cassation.

Determining such functions and responsibilities will help in avoiding the contradictions and speeding up solving the disputes between the opponents, in addition to saving time and money as result of the lengthily pleadings

\section{Conclusion and Recommendations}

\subsection{Conclusion}

This research reached the conclusion the necessity for distinguishing between what inters in the reality limits and what inters in the law limits.

The research also determined the big obstacle which stands behind the inability to determine what reality is and what is law represents in the legislative deficit in the situational laws including the Jordanian civil prosecutions principles law in which we find contradictions and ambiguity in the texts.

Since it is seen that some time assigning and determining the functions, and at other times distributing the procedural tasks between the judge and the opponents in the civil issues, and determining the functions of the judge by the law and the opponents by reality to achieve the desired goal from the law which is the justice based on the cooperation between the judge and the opponents.

We can see the direct effect of this situation on describing court of cassation as a law court, as a supreme court in the state performing the function checking out the dispute from the legal side without looking at the reality, or as $\mathrm{s}$ third degree of the litigations degrees, and the relation of this with the litigation principle at two degrees. If it related the rule it has no right to settle the issue, rather it should return the case back to its source to perform the legal duty.

\footnotetext{
${ }^{108}$ Aboudi, Abbas, p. 400, (Ibid).

109 Egyptian Procedural Law No. 13 of 1986 and its amendments.

${ }^{110}$ Omar, Nabil Isma'il, P. 464, (Ibid).

111 Article 604 of the French Code of Procedure is mentioned earlier.

${ }^{112}$ Art 15 "Les parties doivent se faire connaîtremutuellementen temps utile les moyens de fait sur lesquelsellesfondentleursprétentions, les éléments de preuvequ'ellesproduisentet les moyens de droit qu'ellesinvoquent, afin que chacunesoit à mêmed'organisersa defense".

Art 16 "Le jugedoit, entoutescirconstances, faire observer et observer lui-même le principe de la contradiction. Il ne peutretenir, danssadécision, les moyens, les explications et les documents invoquésouproduits par les parties que sicelles-ci ontété à mêmed'endébattrecontradictoirement. Il ne peut fonder sadécision sur les moyens de droit qu'il a relevésd'office sans avoir au préalableinvité les parties à présenterleurs observations.

Art 604 "Le pourvoiencassation tend à faire censurer par la Cour de cassation la non-conformité du jugementqu'ilattaque aux règles de droit". Modifié par Décret 79-941 1979-11-07 art. 2 JORF 9 novembre 1979 envigueur le 1 janvier 1980.
} 


\subsection{Recommendations}

Based on the discussion, it is recommended the follow:

1- Setting independent legal texts regarding the civil litigation principles law to organize the judge's and the opponent's authority in a technical and accurate way to separate between what is law and what is reality as implemented by the French legislator.

2- Amending text of article (197) from the Jordanian civil litigations principles, and determining function of court of cassation as higher judicial body specializes in looking at the appeal from the legal side.

3- Restricting court of cassation from solving the introduced to it lawsuits from the topic side in case of canceling the decision whatever is the reason, and it should turn the file to the court of subject to solve it once again.

4- Implementing what has been mentioned in the French pleading law regarding the solutions that have been addressed in this research regarding distinguishing between reality and the law, since the French law is considered a distinguish law.

\section{References}

Arabic References

Aboudi, A. (2009). Explanation of the Code of Civil Procedure. House of Culture for publication and distribution.

Aboudi, A. (2009). Explanation of the provisions of the Code of Civil Procedure. House of Culture for publication and distribution, for the year.

Aboudi, A. (2015). Rules and Pleadings. Al-Sharif, Dar al-Sanhoori Law and Political Science, Iraq.

Abu Al Wafa, A. Civil and commercial hearings under the new law of procedures No. 13 of 1968.

Abu Al-Wafa, A. (1985). The Theory of Judgments in the Code of Pleadings. Alexandria, Al-Ma'aref Establishment, No. 5.

Al-Akhras, N. A. (2010). Explanation of Civil Procedure. Dar Al-Thaqafa for Publishing and Distribution, II, Amman.

Al-Hajjar, H. M. (2003). Methodology in Law from Theory to Practice, II. Beirut.

Al-Qassas, A. M. (2010). Al-Wasit in explaining the Civil and Commercial Procedures Law (2nd ed.). Dar Al-Ketub, Cairo.

Al-Sadah, A.-M. F. (1994). Origins of Law. Al-Ma'aref Establishment, Alexandria.

Al-Sanhoury, A. R. A. (2000). Al-Waseet in Explaining Civil Law (Vol. I, C1). Halabi Rights Publications, I3, Beirut.

Al-Sharif, H. (1999). Criminal Cassation, Applied and Analytical Study of the Law of Challenging the Revocation of Criminal Proceedings. University Thought House, Alexandria.

Al-Zu'bi, A. A. (2017). Introduction to the Law science. Enrichment for Publishing and Distribution, Amman, I(4).

Ashmawi, M. (1927). Rules of Pleading in Civil and Mixed Law, Monchaat Al Maaref, Article 1136, C2.

Auji, M. Civil Law - Part II - Civil Liability (3rd ed.). Halabi Publications.

Bakri, A., \& Bashir, Z. (1989). The approach to the study of law. The Higher Education Press, Mosul.

Cherkaoui, J. (1976). Evidence in Civil Materials. Dar al-Nahda al-Arabiya, Cairo.

Desouki, M. I. (1989). The General Theory of Law and the Right in the Libyan Law, II. Cairo University Press.

El-Sawy, A. El. S. (2000). Al-Waseet in explaining the Civil and Commercial Procedures Law. Dar Al-Nahda Al-Arabiya, Cairo.

Fahmi, M. H. (1940). Explanation of Civil and Commercial Pleadings, item 745.

Hindi, A. (2006). Judgments of the Court of Cassation and its impact. New University Publishing House, Alexandria.

Hosny, A. M. H. (2005). The Diamond Encyclopedia (Part VII). Hosny Center for Studies, Cairo.

Ibrahim, M. M. (1982). The General Theory in the Legal Adaptation of the Case in the Law of Pleadings. Dar 
Al-Fikr Al-Arabi, Cairo.

Khater, T. Y. (2014). The Theory of nullification in Civil Procedure Law, 1. Dar Al-Fikr and Law for Publishing and Distribution.

Khater, T. Y. (2014). Theory of Absence in the Civil Procedure Law. House of Thought and Law for Publishing and Distribution.

League, G. The approach to the science of law, especially the Jordanian (I 4). Irbid, Hammad Center.

Mansour, A. M. Al-M. (2013). Explanation of the provisions of the Jordanian Evidence Law, in accordance with the latest amendments, for publication and distribution (3rd ed.). Amman.

Meligy, A. (2005). Encyclopedia of the appeal of judgments, Appeal against the veto. National Center for Legal Issuances, C4, Cairo.

Omar, N. I. (2011). The Mediator in the Appeal by the repealing of civil and commercial articles. New University Publishing House, Alexandria.

Saif, R. (1970). Al-Waseet in explaining the law of pleadings. Dar al-Nahda al-Arabia, i 7, Cairo.

Sawy, A. El S. (2011). Al-Waseet in explaining the law of civil and commercial ports, amended by Law No. 6 of 2007. Dar Al-Nahda Al-Arabia, Cairo.

Shoshari, S. (2010). Explanation of the Code of Civil Procedure. House of Culture for publication and distribution.

Sultan, A. (2005). Rules of Evidence in Civil and Commercial Articles. New University Publishing House.

Sultan, A. (2005). Rules of Evidence in Civil and Commercial Materials. New University Publishing House.

Tawfiq, H. F. (1990). Introduction to Legal Sciences: General Theory of Law. University House.

The Judges, M. A. (2017). Civil Procedure and Judicial Organization. Dar Al-Thaqafa for Publishing and Distribution, No. 2.

Wahab, A., \& Razzaq, A. (1991). Challenging the Provisions of Discrimination in the Law of the Civilhearings. Dar Al-Hikma for Printing and Publishing, Baghdad.

Wali, F.-Z., \& Maher, A. (1997). Theory of Nullity in the law of pleadings. Dar al-Nahda Arab Publishing and Distribution, I 2.

Laws

Jordanian Civil Law No. 43 of 1976.

1- Civil and Commercial Crises Law of the Arab Republic of Egypt No. 13 of 1986 and its amendments.

2- Iraqi Refinance Act No. 107 of 1979.

3- $\quad$ The French Lifts Act No. 1123-75, 1975.

Judgments

1- Decision of the Court of Cassation Rights No. 546/93, 1994.

2- Decision of the Court of Cassation Rights No. 751/96, 1997.

3- Decisions of the Jordanian Court of Cassation No. 7508, 4906, 6329, 7000 and 5348 for the year 2018, published on the Qurtas website.

4- Decision of the Court of Cassation Rights No. 178/84, 1984

5- Decision of the Court of Cassation Rights No. 178/84, 1984.

Foreign references

Rigaux, Lanature du Controle de La de Cassation, Bruxelles, 1966, N50.76. Nouveau Code de Procedure Civile, Dalloze 2002, p.334.

Website

http://bit.ly/2D5rxZg

http://dfgpublish.com/

http://iraqld.hjc.iq 
http://library.philadelphia.edu.jo

http://link.qnl.qa.

http://www.daralnahda.com

https://books.google.jo

https://books-library.online

https://doi.org

https://library.asu.edu

www.biruni.tn

www.codes-et-lois.fr

www.daralnahda.com

www.daralthaqafa.com

www.iraqnla-iq.com

www.jba.org.jo

www.jc.jo

www.law-arab.com

www.legifrance.gouv.fr

www.neelwafurat.com

www.philadelphia.edu.jo

www.qistas.com

\section{Copyrights}

Copyright for this article is retained by the author(s), with first publication rights granted to the journal.

This is an open-access article distributed under the terms and conditions of the Creative Commons Attribution license (http://creativecommons.org/licenses/by/4.0/). 